\title{
Impact Assessment on Income and Employment of Krishi Vigyan Kendra Training Programmes in Nagaland
}

\author{
Imsunaro Jamir and Amod Sharma* \\ Department of Agricultural Economics, Nagaland University SASRD Medziphema Campus, \\ District: Dimapur - 797 106, Nagaland, India \\ *Corresponding author
}

\section{A B S T R A C T}

\section{Keywords}

KVK, Impact, Training, Discipline, Assessment,

Programme, Yield,

Income, Employment

Article Info

Accepted:

15 October 2018

Available Online:

10 November 2018
The present study on access the impact of Krishi Vigyan Kendra (KVK's) for conducting the training programmes in their respective district of the Nagaland state during the year 2012-13 to 2016-17 (five years) and also to assess the impact of income as well as employment generated for that purpose it was categorized into two groups viz., adopted and non-adopted villages (80 respondents to each category which make a total of 160 respondents). To achieve the objectives of the present study a multi stage purpose random sampling methods was adopted. In general, to cover the different aspects 12 numbers of discipline were selected to assess the income and employment, so the overall annual income may be increased by the KVK's adopted villages if the re-allocation of the selected variable were made adjustment for the effectiveness of the different schemes / programme implemented in both the district through different activities to enhanced the income and employment.

\section{Introduction}

Nagaland, the $16^{\text {th }}$ State of the Indian Union, came into being on $01^{\text {st }}$ December 1963. Nagaland with a geographical area of about $16,579 \mathrm{Sq}$. Km. lies between $25^{\circ} 60^{\prime}$ and $27^{\circ} 40^{\prime}$ North latitude and $93^{\circ} 20^{\prime}$ and $95^{\circ} 15^{\prime}$ East longitude. The state is bounded by Assam in the North and West, by Myanmar and Arunachal Pradesh in the East and by Manipur in the South. Nagaland, being one of the "eight Sisters" commonly called as the NorthEastern Region including Sikkim, is a land of lush green forests, rolling Mountains, enchanting valleys, swift flowing streams and of beautiful landscape. The inhabitants of
Nagaland are almost entirely tribal with distinctive dialects and cultural features (Annon, 2017).

The state is predominantly rural with 82.26 per cent of population living in villages. The state comprises of 11 administrative headquarters with 52 blocks and 1,278 inhabited villages. Each district has generally predominance / concentration of one of the major / minor tribe of the state, thereby making districts distinct in their linguistic, cultural, traditional and socio-political characteristics. The topography of Nagaland is much dissected, full of hill ranges, which break into a wide chaos of spurs and ridges. 
The terrain is mountainous covered by rich and varied biodiversity of flora and fauna. It is one of the 25 hot spots of the world with respect to its biological diversity, and hence can be termed as the state of true Mega biodiversity. The state houses the confluence of flora and fauna of the neighbouring regions. Geographically, the state largely has vast undulating terrain and hilly landscape and some low lying areas giving rise to a very conducive climate with presence of perennial water and moisture for truly rich variety of flora and fauna (Anon., 2017).

The state also has abundant resources of mineral wealth in the form of vast deposits of Oil, Coal, Peat, Limestone, Iron ores and various other minerals. The potential of this state in terms of the sheer variety of Agro and Horticultural produce including Fiber, Tea, Coffee, Pineapple, Orange etc. is also immense. In spite of this inherent potential, the state has not developed. The current practice of agriculture is largely unsustainable owing to the traditional Jhum (Shifting cultivation) cycle mode of operation. Though some dynamic initiatives (e. g; by various government, Department, NGO's etc.) are in action to mitigate the detrimental effects of Jhum, a lot still needs to be done on various fronts including efforts on checking deforestation, control of wild fire, conservation of biodiversity, proper water harvesting, use of non-conventional energy sources etc.

The state also lacks infrastructure development in terms of networking with the rest of the country, lack of proper communication in terms of roads and information technology.

Krishi Vigyan Kendras (Farm Science Centre), an innovative science based institutions, are the only district - level institutions with a proven potentiality to build farmers' capacity on their multi-dimensional requirements in a scientific and systematic approach which is established mainly to impart vocational training to the farmers and field level extension workers. The concept of vocational training in agriculture through KVK grew substantially due to greater demand for improved agricultural technology by the farmers. They not only required knowledge and understanding of the intricacy of technologies, but also progressively more and more skills in various complex agricultural operations for adoption on their farms.

The effectiveness of the KVK was further enhanced by adding the activities related to on-farm testing and Front-Line Demonstration on major agricultural technologies in order to make the training of farmers location specific, need based and resource-oriented. The training programmes were designed to impart the latest knowledge to the farmers through work experience by applying the principles of 'Teaching by Doing' and 'Learning by Doing'.

The prime goal of KVK is to impart training as per needs and requirements in agriculture and allied enterprises to all farmers, farm women and farm youths including school drop-outs in the rural area. While designing the courses, the concept of farming system as well as farming situation are taken into account to ensure that the enterprises in which they are trained are commercially and ecologically viable, sustainable and profitable. Such vocational trainings help them to sustain themselves through self-employment and to make them self-reliant economically and thus discourages them to migrate to the urban areas. KVKs provide training not only in agriculture and allied vocations but also in other income-generating activities that may supplement the income of farm families. The methods employed in training could be formal 
and non-formal or a combination of both, depending upon the needs but emphasis remains to be on work-experience. The programme of each KVK covers training, onfarm trials, frontline demonstrations, agricultural extension and livelihood activities. Keeping in view the above fact, the present study is undertaken to access the Impact of KVK's training in terms of income and employment.

\section{Materials and Methods}

The present study is to access the impact of KVK for disseminating the agriculture technology to the farming community in Nagaland state, which is working as per the guideline of Central Government with the help of Ministry of Agriculture, Government of India. Since the intensive KVK started in 1988-89, so it is worth -while to study its impact.

Since the data of the initial period cannot be compared with the data of recent years, it is more scientific and practical to compare the economy of the beneficiaries / trainees covered in the area of KVK schemes. The KVK was launched in 1988-89 in all 11 districts viz; Dimapur, Kohima, Kheprie, Longleng, Mokokchung, Mon, Phek, Peren, Tuensang, Wokha and Zunhebuto of Nagaland, out of these districts two district viz; Mokokchung and Zunhebuto districts of Nagaland have been selected because of the fact that it is expected to provide all the relevant information and hence can conveniently be obtained for conducting this study.

Keeping all the above facts, both districts of Nagaland are therefore purposively selected to conduct this study. Two blocks from each district will be selected randomly for the present study as these blocks are well covered by KVK programme. Altogether eight villages were selected randomly from each district, while four villages from each block were selected and listed which would be obtained from the offices of SDO (Civil), R. D. block headquarter and other related offices. However, it is proposed to select four villages from each block randomly covered for KVK programme / schemes. After selection of the villages, a list of beneficiaries and nonbeneficiaries of KVK will be prepared from each of the selected village. In order to have representative sample from each village a sample of 20 numbers of cases of KVK, out of that 10 from beneficiaries and 10 from nonbeneficiaries will be drawn following the purposively random sampling method. This will result in selection of 160 respondents from 8 villages, out of which 80 will be beneficiaries of KVK schemes and 80 will be non-beneficiaries of KVK schemes.

\section{Results and Discussions}

Table 1 reveals the status of area (in acre) and yield (in $\mathrm{kg}$ ) for the different food grain crops which was selected for the large and overall farm size groups, as both the farm were found to be significant at 1 and 5 per cent level on the cereals and pulses crops, respectively. While the oilseed crop on marginal, medium and overall farm size were found to be significant at 1 and 5 per cent level on area, yield was also recorded as significant too.

Whereas the horticultural aspects overall area and yield both were found to be significant on both the marginal and small farm size group, even the yield also found to be significant at 5 per cent level. The marginal, medium and overall farm size group for the other crops were found to be significant at 1 and 5 per cent level. However, on the marginal, small and medium farm size group the miscellaneous crop were found to be significant at 1 and 5 per cent level of probability, respectively. 
Table.1 Status of area (acre) and yield (Kg) for different food grains crops

\begin{tabular}{|c|c|c|c|c|c|c|c|}
\hline \multirow[t]{2}{*}{ Category } & \multirow{2}{*}{$\begin{array}{l}\text { 1. a. Cereals } \\
\text { Before }\end{array}$} & \multicolumn{6}{|c|}{ Area (acre) } \\
\hline & & $\%$ & After & $\%$ & Impac & Difference \% & 't' test \\
\hline Marginal & 19 & 23.75 & 16 & 20.00 & 3 & 3.75 & NS \\
\hline Small & 47 & 58.75 & 45 & 56.25 & 2 & 2.50 & NS \\
\hline Medium & 14 & 17.50 & 19 & 23.75 & 5 & 6.25 & * \\
\hline Overall & 80 & 100.00 & 80 & 100.0 & 10 & 12.50 & * \\
\hline Category & 1. b. Cereals & \multicolumn{6}{|c|}{ Yield (Kg) } \\
\hline Marginal & 20 & 25.00 & 17 & 21.25 & 3 & 3.75 & NS \\
\hline Small & 46 & 57.50 & 44 & 55.00 & 2 & 2.50 & NS \\
\hline Medium & 14 & 17.50 & 19 & 23.75 & 5 & 6.25 & * \\
\hline Overall & 80 & 100.00 & 80 & 100.0 & 10 & 12.50 & $*$ \\
\hline Category & 2. a. Pulses & \multicolumn{6}{|c|}{ Area (acre) } \\
\hline Marginal & 55 & 68.75 & 52 & 65.00 & 3 & 3.75 & NS \\
\hline Small & 15 & 18.75 & 12 & 15.00 & 3 & 3.75 & NS \\
\hline Medium & 10 & 12.50 & 16 & 20.00 & 6 & 7.50 & * \\
\hline Overall & 80 & 100.00 & 80 & 100.0 & 12 & 15.00 & $* *$ \\
\hline Category & 2. b. Pulses & \multicolumn{6}{|c|}{ Yield (Kg) } \\
\hline Marginal & 61 & 76.25 & 55 & 68.75 & 6 & 7.50 & $*$ \\
\hline Small & 9 & 11.25 & 10 & 12.50 & 1 & 1.25 & NS \\
\hline Medium & 10 & 12.50 & 15 & 18.75 & 5 & 6.25 & * \\
\hline Overall & 80 & 100.00 & 80 & 100.0 & 12 & 15.00 & $* *$ \\
\hline Category & 3. a. Oilseeds & \multicolumn{6}{|c|}{ Area (acre) } \\
\hline Marginal & 64 & 80.00 & 54 & 67.50 & 10 & 12.50 & $*$ \\
\hline Small & 7 & 8.75 & 11 & 13.75 & 4 & 5.00 & NS \\
\hline Medium & 9 & 11.25 & 15 & 18.75 & 6 & 7.50 & * \\
\hline Overall & 80 & 100.00 & 80 & 100.0 & 20 & 25.00 & $* *$ \\
\hline Category & 3. b. Oilseeds & \multicolumn{6}{|c|}{ Yield (Kg) } \\
\hline Marginal & 63 & 78.75 & 52 & 65.00 & 11 & 13.75 & $* *$ \\
\hline Small & 8 & 10.00 & 14 & 17.50 & 6 & 7.50 & $*$ \\
\hline Medium & 9 & 11.25 & 14 & 17.50 & 5 & 6.25 & * \\
\hline Overall & 80 & 100.00 & 80 & 100.0 & 22 & 27.50 & ** \\
\hline Category & 4. a. Horticult & \multicolumn{6}{|c|}{ Area (acre) } \\
\hline Marginal & 55 & 68.75 & 51 & 63.75 & 4 & 5.00 & NS \\
\hline Small & 11 & 13.75 & 14 & 17.50 & 3 & 3.75 & NS \\
\hline Medium & 14 & 17.50 & 15 & 18.75 & 1 & 1.25 & NS \\
\hline Overall & 80 & 100.00 & 80 & 100.0 & 8 & 10.00 & * \\
\hline Category & 4. b. Horticut & \multicolumn{6}{|c|}{ Yield (Kg) } \\
\hline Marginal & 60 & 75.00 & 51 & 63.75 & 9 & 11.25 & * \\
\hline Small & 12 & 15.00 & 10 & 12.50 & 2 & 2.50 & NS \\
\hline Medium & 8 & 10.00 & 19 & 23.75 & 11 & 13.75 & $*$ \\
\hline Overall & 80 & 100.00 & 80 & 100.0 & 22 & 27.50 & $* *$ \\
\hline
\end{tabular}




\begin{tabular}{|l|c|c|c|c|c|c|c|c|}
\hline Category & 5. a. Other crop & \multicolumn{7}{|c|}{ Area (acre) } \\
\hline Marginal & 59 & 73.75 & 51 & 63.75 & 8 & 10.00 & $*$ \\
\hline Small & 12 & 15.00 & 15 & 18.75 & 3 & 3.75 & NS \\
\hline Medium & 9 & 11.25 & 14 & 17.50 & 5 & 6.25 & $*$ \\
\hline Overall & 80 & 100.00 & 80 & 100.0 & 16 & 20.00 & $* *$ \\
\hline Category & 5. b. Other crop & & \multicolumn{5}{|c|}{ Yield (Kg) } \\
\hline Marginal & 56 & 70.00 & 52 & 65.00 & 4 & 5.00 & NS \\
\hline Small & 16 & 20.00 & 12 & 15.00 & 4 & 5.00 & NS \\
\hline Medium & 8 & 10.00 & 16 & 20.00 & 8 & 10.00 & $*$ \\
\hline Overall & 80 & 100.00 & 80 & 100.0 & 16 & 20.00 & $* *$ \\
\hline Category & 6. a. Mis. crops & & & Area (acre) & & \\
\hline Marginal & 50.4 & 63 & 44.8 & 56 & 5.6 & 17 & $* *$ \\
\hline Small & 18.4 & 23 & 19.4 & 24.25 & 3 & 3.75 & NS \\
\hline Medium & 11.2 & 14 & 15.8 & 19.75 & 4.6 & 5.75 & $*$ \\
\hline Overall & 80 & 100 & 80 & 100.0 & 13.2 & 16.5 & $* *$ \\
\hline Category & 6. b. Mis. crops & & \multicolumn{7}{|c|}{ Yield (Kg) } & & \\
\hline Marginal & 52 & 65 & 45.4 & 56.75 & 6.6 & 8.25 & $*$ \\
\hline Small & 18.2 & 22.75 & 18 & 22.5 & 3 & 3.75 & NS \\
\hline Medium & 9.8 & 12.25 & 16.6 & 20.75 & 6.8 & 8.5 & $*$ \\
\hline Overall & 80 & 100 & 80 & 100.0 & 16.4 & 15.75 & $* *$ \\
\hline (** \& *ignificant at 1.5 per cent level of significant, NS: Non Significant) & & & \\
\hline
\end{tabular}

Table.2 Status of income and employment through KVK interventions

\begin{tabular}{|c|c|c|c|c|c|c|}
\hline 1.a. Agronomy & \multicolumn{6}{|c|}{ Income } \\
\hline Before & $\%$ & After & $\%$ & Impact & Impact \% & 't' test \\
\hline Marginal 18 & 22.50 & 14 & 17.50 & 4 & 5.00 & NS \\
\hline Small 54 & 67.50 & 56 & 70.00 & 2 & 2.50 & NS \\
\hline Medium 8 & 10.00 & 10 & 12.50 & 2 & 2.50 & NS \\
\hline Overall 80 & 100.00 & 80 & 100.00 & 8 & 10.00 & $*$ \\
\hline 1. b. Agronomy & \multicolumn{6}{|c|}{ Employment } \\
\hline Marginal 17 & 21.25 & 13 & 16.25 & 4 & 5.00 & NS \\
\hline Small 53 & 66.25 & 55 & 68.75 & 2 & 2.50 & NS \\
\hline Medium 10 & 12.50 & 12 & 15.00 & 2 & 2.50 & NS \\
\hline Overall 80 & 100.00 & 80 & 100.00 & 8 & 10.00 & $*$ \\
\hline 2.a. Horticulture & \multicolumn{6}{|c|}{ Income } \\
\hline Marginal 6 & 7.50 & 4 & 5.00 & 2 & 2.50 & NS \\
\hline Small 60 & 75.00 & 58 & 72.50 & 2 & 2.50 & NS \\
\hline Medium 14 & 17.50 & 18 & 22.50 & 4 & 5.00 & NS \\
\hline Overall 80 & 100.00 & 80 & 100.00 & 8 & 10.00 & $*$ \\
\hline 2. b. Horticulture & \multicolumn{6}{|c|}{ Employment } \\
\hline Before & $\%$ & After & $\%$ & Impact & Impact \% & 't' test \\
\hline Marginal 8 & 10.00 & 6 & 7.50 & 2 & 2.50 & NS \\
\hline Small 68 & 85.00 & 68 & 85.00 & 0 & 0.00 & NS \\
\hline Medium 4 & 5.00 & 12 & 15.00 & 8 & 10.00 & $*$ \\
\hline Overall 80 & 100.00 & 80 & 107.50 & 10 & 12.50 & $*$ \\
\hline 3. a. Entomology & \multicolumn{6}{|c|}{ Income } \\
\hline
\end{tabular}




\begin{tabular}{|c|c|c|c|c|c|c|}
\hline Marginal 0 & 0.00 & 0 & 0.00 & 0 & 0.00 & NS \\
\hline Small 68 & 85.00 & 65 & 81.25 & 3 & 3.75 & NS \\
\hline Medium 12 & 15.00 & 15 & 18.75 & 3 & 3.75 & NS \\
\hline Overall 80 & 100.00 & 80 & 100.00 & 6 & 7.50 & * \\
\hline 3. b. Entomology & \multicolumn{6}{|c|}{ Employment } \\
\hline Marginal 0 & 0.00 & 0 & 0.00 & 0 & 0.00 & NS \\
\hline Small 69 & 86.25 & 68 & 85.00 & 1 & 9.09 & $*$ \\
\hline Medium 11 & 13.75 & 12 & 15.00 & 1 & 1.25 & NS \\
\hline Overall 80 & 100.00 & 80 & 100.00 & 2 & 10.34 & $*$ \\
\hline 4. a. PLP & \multicolumn{6}{|c|}{ Income } \\
\hline Marginal 0 & 0.00 & 0 & 0.00 & 0 & 0.00 & NS \\
\hline Small 76 & 95.00 & 74 & 92.50 & 2 & 2.50 & NS \\
\hline Medium 4 & 5.00 & 6 & 7.50 & 2 & 2.50 & NS \\
\hline Overall 80 & 100.00 & 80 & 100.00 & 4 & 5.00 & NS \\
\hline 4. b. PLP & \multicolumn{6}{|c|}{ Employment } \\
\hline Marginal 0 & 0.00 & 0 & 0.00 & 0 & 0.00 & NS \\
\hline Small 75 & 93.75 & 73 & 91.25 & 2 & 2.50 & NS \\
\hline Medium 5 & 6.25 & 7 & 8.75 & 2 & 2.50 & NS \\
\hline Overall 80 & 100.00 & 80 & 100.00 & 4 & 5.00 & NS \\
\hline 5. a. Soil Science & \multicolumn{6}{|c|}{ Income } \\
\hline Marginal 18 & 22.50 & 12 & 15.00 & 6 & 7.50 & $*$ \\
\hline Small 50 & 62.50 & 52 & 65.00 & 2 & 2.50 & NS \\
\hline Medium 12 & 15.00 & 16 & 20.00 & 4 & 5.00 & NS \\
\hline Overall 80 & 100.00 & 80 & 100.00 & 12 & 15.00 & $* *$ \\
\hline 5. b. Soil Science & \multicolumn{6}{|c|}{ Employment } \\
\hline Marginal 28 & 35.00 & 22 & 27.50 & 6 & 7.50 & $*$ \\
\hline Small 44 & 55.00 & 42 & 52.50 & 2 & 2.50 & NS \\
\hline Medium 8 & 10.00 & 16 & 20.00 & 8 & 10.00 & $*$ \\
\hline Overall 80 & 100.00 & 80 & 100.00 & 12 & 15.00 & $* *$ \\
\hline 6. a. Fishery Science & \multicolumn{6}{|c|}{ Income } \\
\hline Marginal 0 & 0.00 & 0 & 0.00 & 0 & 0.00 & NS \\
\hline Small 66 & 82.50 & 64 & 80.00 & 2 & 2.50 & NS \\
\hline Medium 14 & 17.50 & 16 & 20.00 & 2 & 2.50 & NS \\
\hline Overall 80 & 100.00 & 80 & 100.00 & 4 & 5.00 & NS \\
\hline 6. b. Fishery Science & \multicolumn{6}{|c|}{ Employment } \\
\hline Marginal 0 & 0.00 & 0 & 0.00 & $\mathbf{0}$ & 0.00 & NS \\
\hline Small 76 & 95.00 & 74 & 92.50 & 2 & 2.50 & NS \\
\hline Medium 4 & 5.00 & 6 & 7.50 & 2 & 2.50 & NS \\
\hline Overall 80 & 100.00 & 80 & 100.00 & 4 & 5.00 & NS \\
\hline 7. a. Home Science & \multicolumn{6}{|c|}{ Income } \\
\hline Before & $\%$ & After & $\%$ & Impact & Impact \% & 't' test \\
\hline Marginal 0 & 0.00 & $\mathbf{0}$ & 0.00 & 0 & 0.00 & NS \\
\hline Small 76 & 95.00 & 74 & 92.50 & 2 & 2.50 & NS \\
\hline Medium 4 & 5.00 & 6 & 7.50 & 2 & 2.50 & NS \\
\hline Overall 80 & 100.00 & 80 & 100.00 & 4 & 5.00 & NS \\
\hline 7. b. Home Science & \multicolumn{6}{|c|}{ Employment } \\
\hline Marginal 0 & 0.00 & 0 & 0.00 & 0 & 0.00 & NS \\
\hline Small 76 & 95.00 & 75 & 93.75 & 1 & 1.25 & NS \\
\hline Medium 4 & 5.00 & 5 & 6.25 & 1 & 1.25 & NS \\
\hline Overall 80 & 100.00 & 80 & 100.00 & 2 & 2.50 & NS \\
\hline 8. a. Post Harvest M & & & & Income & & \\
\hline
\end{tabular}




\begin{tabular}{|c|c|c|c|c|c|c|}
\hline Marginal 16 & 20.00 & 14 & 17.50 & 2 & 2.50 & NS \\
\hline Small50 & 62.50 & 48 & 60.00 & 2 & 2.50 & NS \\
\hline Medium 14 & 17.50 & 18 & 22.50 & 4 & 5.00 & NS \\
\hline Overall 80 & 100.00 & 80 & 100.00 & 8 & 10.00 & $*$ \\
\hline \multicolumn{2}{|c|}{ 8. b. Post Harvest Management } & \multicolumn{4}{|c|}{ Employment } & \\
\hline Marginal 22 & 27.50 & 18 & 22.50 & 4 & 5.00 & NS \\
\hline Small 48 & 60.00 & 46 & $\mathbf{5 7 . 5 0}$ & 2 & 2.50 & NS \\
\hline Medium 10 & 12.50 & 16 & 20.00 & 6 & 7.50 & * \\
\hline Overall 80 & 100.00 & 80 & 100.00 & 12 & 15.00 & $* *$ \\
\hline 9. a. Tailoring & \multicolumn{6}{|c|}{ Income } \\
\hline Marginal 0 & 0.00 & $\mathbf{0}$ & 0.00 & $\mathbf{0}$ & 0.00 & NS \\
\hline Small 71 & 88.75 & 70 & 87.50 & 1 & 1.25 & NS \\
\hline Medium 9 & 11.25 & 10 & 12.50 & 1 & 1.25 & NS \\
\hline Overall 80 & 100.00 & 80 & 100.00 & 2 & 2.50 & NS \\
\hline 9. b. Tailoring & Employ & & & & & \\
\hline Marginal 0 & 0.00 & 0 & 0.00 & 0 & 0.00 & NS \\
\hline Small 72 & 90.00 & 70 & 87.50 & 2 & 2.50 & NS \\
\hline Medium 8 & 10.00 & 10 & 12.50 & 2 & 2.50 & NS \\
\hline Overall 80 & 100.00 & 80 & 100.00 & 4 & 5.00 & NS \\
\hline 10. a. Cottage Industries & \multicolumn{6}{|c|}{ Income } \\
\hline Marginal 0 & 0.00 & $\mathbf{0}$ & 0.00 & O & 0.00 & NS \\
\hline Small 75 & 93.75 & 73 & 91.25 & 2 & 2.50 & NS \\
\hline Medium 5 & 6.25 & 7 & 8.75 & 2 & 2.50 & NS \\
\hline Overall 80 & 100.00 & 80 & 100.00 & 4 & 5.00 & NS \\
\hline 10. b. Cottage Industries & \multicolumn{6}{|c|}{ Employment } \\
\hline Marginal 0 & 0.00 & 0 & 0.00 & 0 & 0.00 & NS \\
\hline Small 70 & 87.50 & 67 & 83.75 & 3 & 3.75 & NS \\
\hline Medium 10 & 12.50 & 13 & 16.25 & 3 & 3.75 & NS \\
\hline Overall 80 & 100.00 & 80 & 100.00 & 6 & 7.50 & NS \\
\hline 11. a. Small Scale Industries & \multicolumn{6}{|c|}{ Income } \\
\hline Marginal 0 & 0.00 & $\mathbf{0}$ & 0.00 & 0 & 0.00 & NS \\
\hline Small 76 & 95.00 & 74 & 92.50 & 2 & 2.50 & NS \\
\hline Medium 4 & 5.00 & 6 & $\mathbf{7 . 5 0}$ & 2 & 2.50 & NS \\
\hline Overall 80 & 100.00 & 80 & 100.00 & 4 & 5.00 & NS \\
\hline 11. b. Small Scale Industries & \multicolumn{6}{|c|}{ Employment } \\
\hline Before & $\%$ & After & $\%$ & Impact & Impact \% & 't' test \\
\hline Marginal 0 & 0.00 & $\mathbf{0}$ & 0.00 & 0 & 0.00 & NS \\
\hline Small 76 & 95.00 & 73 & 91.25 & 3 & 3.75 & NS \\
\hline Medium 4 & 5.00 & 7 & 8.75 & 3 & 3.75 & NS \\
\hline Overall 80 & 100.00 & 80 & 100.00 & 6 & 7.50 & NS \\
\hline 12. a. Others & \multicolumn{6}{|c|}{ Income } \\
\hline Marginal 0 & 0.00 & 0 & 0.00 & O & 0.00 & NS \\
\hline Small 78 & 97.50 & 74 & 92.50 & 4 & 5.00 & NS \\
\hline Medium 2 & 2.50 & 6 & 7.50 & 4 & 5.00 & NS \\
\hline Overall 80 & 100.00 & 80 & 100.00 & 8 & 10.00 & $*$ \\
\hline 12. b. Others & \multicolumn{6}{|c|}{ Employment } \\
\hline Marginal 0 & 0.00 & 0 & 0.00 & 0 & 0.00 & NS \\
\hline Small 79 & 98.75 & 75 & 93.75 & 4 & 5.00 & NS \\
\hline Medium 1 & 1.25 & 5 & 6.25 & 4 & 5.00 & NS \\
\hline Overall 80 & 100.00 & 80 & 100.00 & 8 & 10.00 & $*$ \\
\hline
\end{tabular}

(** \& * Significant at 1, 5 per cent level of significant, NS: Non Significant) 
Table 2 reveals the status of income and employment generated after the adopted of KVK's scheme / programme implemented / launched with special reference to the selected 12 (Twelve) different disciplines prevailing in the research selected field / areas viz; agronomy, horticulture, entomology, tailoring, plant pathology, soil science, fishery science, home science, postharvest management, cottage industries, small scale industries,

Others all the selected variables were assess the impact on income and employment generated however only six (50.00 per cent) of them were having positive response, while remaining 50.00 per cent were found to be non-significant role with reference to generate income and employment.

Out of the 12 selected variables the agronomical as well as horticultural both the aspects on the income and employment were found to be significant on overall farm size at 5 per cent level, however on horticulture aspects on the medium farm size employment was also found to be significant at 5 per cent level, respectively.

The entomology aspects was found to be significant on overall farm size group with reference to income and employment, even the small farm size group was found to be significant at 5 per cent level of probability.

The soil science aspects was found to be significant on both the farm size group marginal and overall with reference to income and employment, even on the large farm size group employment was found to be significant at 5 per cent level of probability.

The post-harvest management aspect was found to be significant on overall farm size group on income and employment both, even the employment aspect was also found to be significant on employment at 5 per cent level. Lastly the other aspects on overall farm size group were found to be significant at 5 per cent level of probability, respectively.

\section{Policy Implications}

The following policies may be recommended for the implementation based on the research / field work was carried out for the betterment in the future.

Through market intelligence, market research and marketing extension in the area the marketing margin should be improved.

To make the farmers easily accessible for selling their produce in less time in the nearby market area with less damage and losses the proper transportation system is required.

The agriculture extension workers need to gear up their activities with full force to train the farmers for the effective control of insect, pest and diseases.

To avoid the price fluctuation of the produce and for improvisation of the marketing system, government should establish a regulate market in the local areas.

\section{References}

Ahmad Nafees Singh SP and Parihar P. 2012. Farmer's Assessment of KVK training programme. Economic Affairs. 57(2): 165-168.

Analogous. 2017. Statistical Hand of Nagaland Published by Directorate of 
Economics and Statistics (various issues), Kohima, Nagaland.

Dhakre, D. S. and Sharma, Amod. 2010. Socio-Economic Development in India. Environment and Ecology. 4(1): 2469-2472.

Dubey AK Srivastva JP Singh RP and Sharma VK 2008. Impact of KVK training programme on socioeconomic status and knowledge of trainees in Allahabad district. Indian Research Journal of Extension Education. 8(2-3): 60-61.

Gaikwad SP Godase SS Tambe BN. 2011. Knowledge gained by farmer by participating in field days organized by K.V.K. Pune. International Journal of Agricultural Sciences. 7(2): 460461.

Kadam MS Pandya RD Kolgane BT and Khogare DT. 2012. Constraints faced by the experts working at KVK's. Agriculture Update. 7(1-2): 102-164.

Mishra RP Singh AK and Chaudhary RP. 2005. Impact of KVK on farm women development. Farm Science Journal. 14(1): 67-68.

Pongener, Bendangjungla and Sharma, Amod. 2018. Constraints Faced by the Fishery Enterprises: A SWOC Analysis. IJCMAS. 7(5). May: 15951603.

Rao NV Ratnakar R and Jain PK. 2012. Impact of farmer field schools in KVK adopted villages on level of knowledge and extent of adoption of improved practices of paddy (Oryza sativa L.). Journal of Research ANGRAU. 40(1): 35-41.

Sharma, A. and Sharma, Anamika. 2008. Problems faced by the farmers in adoption of improved maize cultivation practices in hills. TJRAR. 8(2): 22-23.
Sharma, Amod. 2011. Economic and Constraints of King Chilli Growers in Dimapur District of Nagaland. Journal of Interacademicia. 15(4): 710-719.

Sharma, Amod. 2012. Inter-state Disparities in Socio-economic Development in North East Region of India. Journal of Agricultural Science. 4(9). September: 236-243.

Sharma, Amod.; Kichu, Yimkumba. and Sharma, Pradeep. Kumar. 2018. Sustainable economic analysis and constraints faced by the pineapple growers in Nagaland. Progressive Agriculture. 18(1). February: 27-33.

Sharma, Amod; Kichu, Yimkumba. and Chaturvedi, B. K. 2016. Economics and Constraints of Pineapple Cultivation in Dimapur District of Nagaland. TJRAR. 16(1). January: 7275.

Shuya, Keviu. and Sharma, Amod. 2014. Impact and constraints faced by the borrowers of cooperative bank finance in Nagaland. Economic Affairs. 59(4). October: 561-567.

Shuya, Keviu. and Sharma, Amod. 2018. Problems faced by the Borrowers in Utilization and Acquiring of Cooperative Bank Loans in Nagaland. IJED. 14(2). April-June: 52-56.

Singh Dan Singh RP Singh RL and Singh Surat. 2007. Assessment of training programmes of KVK Rampur, its duration and preference time of training programmes. Progressive Research. 2(1-2): 126-128.

Walling, Imti. and Sharma, Amod. 2015. Impact of SGRY on beneficiaries and non-beneficiaries in Dimapur district of Nagaland. TJRAR. 15(2). August: 90-94.

Walling, Imti.; Sharma, Amod.; Yadav, Mukesh. Kumar.; Rajbhar, Arun, Kumar. and Kalai, Kankabati. 2017. 
Impact of Agricultural Technology Management Agency on Rural Economy of Nagaland, India. Plant Archiver. 17(2). October: 1511-1516.
Yerpude Seema and Khare NK. 2003. Constraints in participation of tribal women in watershed programme. Indian Journal of Extension Education. 3(2): 87-88.

\section{How to cite this article:}

Imsunaro Jamir and Amod Sharma. 2018. Impact Assessment on Income and Employment of Krishi Vigyan Kendra Training Programmes in Nagaland. Int.J.Curr.Microbiol.App.Sci. 7(11): 1892-1901. doi: https://doi.org/10.20546/ijcmas.2018.711.214 